\title{
INTEGRATIVE AND MODELING APPROACH TO SUSTAINABILITY MODES OF LIVING AND NEIGHBOURHOOD DEVELOPMENT
}

\author{
TSELISO MOROKE ${ }^{1}$, CAREL SCHOEMAN ${ }^{1} \&$ ILSE SCHOEMAN $^{2}$ \\ ${ }^{1}$ Subject Group for Urban and Regional Planning, North-West University, South Africa \\ ${ }^{2}$ Mathematics and Applied Mathematics, North-West University, South Africa
}

\begin{abstract}
There exists a challenge in achieving equity within urban areas - urban neighbourhoods' spatial and socio-economic inequalities remain considerably ambiguous in regard to urban form and quality of life. A point of departure in urban planning and development is sustainable development, as it has emerged as the principal expression and application of sustainability. It asserts its importance as the main topic of many international conferences. Notably, urban (spatial) planning and sustainable development dimensions need to dovetail their sustainability efforts for the transformation and integration of urban areas. In the interest of quality of life and urban form, from the technical assessment perspective, urban developments, (service) delivery strategies and accessibility generate parallel socio-economic benefits, enabling households and communities to improve their quality of living, and they are further linked to spatial planning processes. Spatial planning requires that sustainable modes of living, social services and economic opportunities be provided spatially in a manner that is rationally based on people's needs and the access distance norms and standards. From this spatial planning perspective, the importance of adopting a measuring system is highlighted - it is difficult to achieve sustainable urban development without determining the degree of sustainability initiatives and/or sustainable modes of living. On this basis, this paper aims to use a model approved for evaluating low-income neighbourhoods' sustainability in South Africa (Successful Neighbourhood Model (SNM)) to integrate strategies and to build the information and knowledge base from which the trajectories of different types of neighbourhoods can be assessed for quality of life. Thus, neighbourhood sustainability indicators are used as the main framework for the analysis in this study, and as a way of implementing SNM. The paper concludes by outlining the potential implementation opportunities/solutions that SNM can offer to achieve desired/satisfactory quality of life and to deliver support to capacitate local and national governments in the development and implementation of urban strategies and policies.
\end{abstract}

Keywords: neighbourhood, sustainability, quality of life, measurement.

\section{INTRODUCTION}

Sustainability has increasingly become a central tenet and consideration in the planning of neighbourhoods. The influence of sustainability discourse emerges at meetings such as United Nations Environment Programme (UNEP) Sustainable Cities Earth Summits, United Nations (UN)-Habitat Conferences, World Urban Campaign Meetings, Wessex Institute Sustainable City Conferences, URBAN21 Conferences and South African Planning Institute Conferences, among many other initiatives. From a narrow point of view, these conferences tackle the multi-disciplinary aspects of urban planning, ranging from wide and numerous issues such as urban planning, sustainability issues, liveability factors, quality of living, sprawling urban development, the amount of resources and services needed, transportation issues, spatial systems and the complexity of modern society, to the few discussed in UN-Habitat reports, among others. Consequently, a consistent upsurge of interest is present to convey a message that urban settings are still unbalanced and outstandingly conjoined to urbanisation effects, which manifest in socio-economic and spatial segregation, poverty and environmental degradation. As a result of these 
sustainability perennial concerns, it becomes imperative to consider what true quality of life and sustainable development are - these are indicators for measuring sustainability and the quality of life that have become an international trend [1].

With respect to various reviews and reflections [2], [3], the understanding of this research paper is that quality of life is the function of (or it will result on the basis of) the degree and the interaction of urban systems - typical interdisciplinary interactions between transportation and land use; neighbourhoods and institutions; social-cultural, economic and infrastructural management; and transitional triggers and change. As a result, the ultimate goal is to understand the process by which sustainability and urban systems can be quantified in order to measure and evaluate quality of life and sustainability objectives in neighbourhoods/cities. The acquired knowledge will then be used to draw conclusions and make recommendations on how the decision framework can be positioned within urban planning and development strategic imperatives for quality of life and sustainable urban development. Therefore, based on the body of literature, the quality of life concept has been a popular topic of discussion [1], and research in many studies in reaction to the challenges facing urban areas (such as traffic, crime or social exclusion) [4] justifies our investigation in this paper.

\section{DEFINITION AND CONTEXTUALISATION OF THE QUALITY OF LIFE}

A fundamental key factor of quality of life is the relationship between people and their everyday urban environments [5]. The correlation is such that the quality of life increases in importance in the hierarchy of human needs [6]. For example, with a desire for a good environment, places have environmental attributes that can be designed to enhance the quality of individual lives [7]. In-depth, quality of life is a broad concept that is embraced and fenced by a number of different disciplines (within sociology, psychology, human geography, environmental design and urban planning) [8]. From the urban planning perspective, this point is reiterated by Yuan et al. [6], who state that quality of life is a multi-faceted concept, embracing such material aspects as level of living, availability of physical and social infrastructure facilities, as well as the less tangible issues of life, such as good health and opportunities for recreation and play. The wave of influence of the quality of life concept in urban planning is given credence by its established strong position in local, national, continental as well as international platforms such as the UN. It has asserted its importance through intensive research in the past decades and appears to have become a quintessential floating signifier within urban planning.

As an interdisciplinary and interdimensional theme, quality of life is interpolated and embodied in conceptualising and defining many theories, methods and concepts. For example, the Economist Intelligence Unit that undertakes liveability surveys refers to liveability as a measure of urban quality of life assessing stability, healthcare, culture and environment, education and infrastructure [9]. Within urban planning, there are relationships between quality of life and a reasonable number of concepts. One such concept is ideopolis - defined as a city whose economic success is driven by knowledge and that has a high quality of life [10], as illustrated in Fig. 1. Generally, there is an impressive body of literature that marries the quality of life notion and the sustainability concept, incorporating quality of life into many of the sustainability concepts, theories and methods, as well as using it as an indicator aimed at evaluating and measuring sustainability. Notably, elements of quality of life in urban settings are represented in comparative models to understand the factors making up a complete entity that can be measured through a set of quality of life sub-dimensions with an associated number of indicators for each (physical, environmental, mobility, social, 


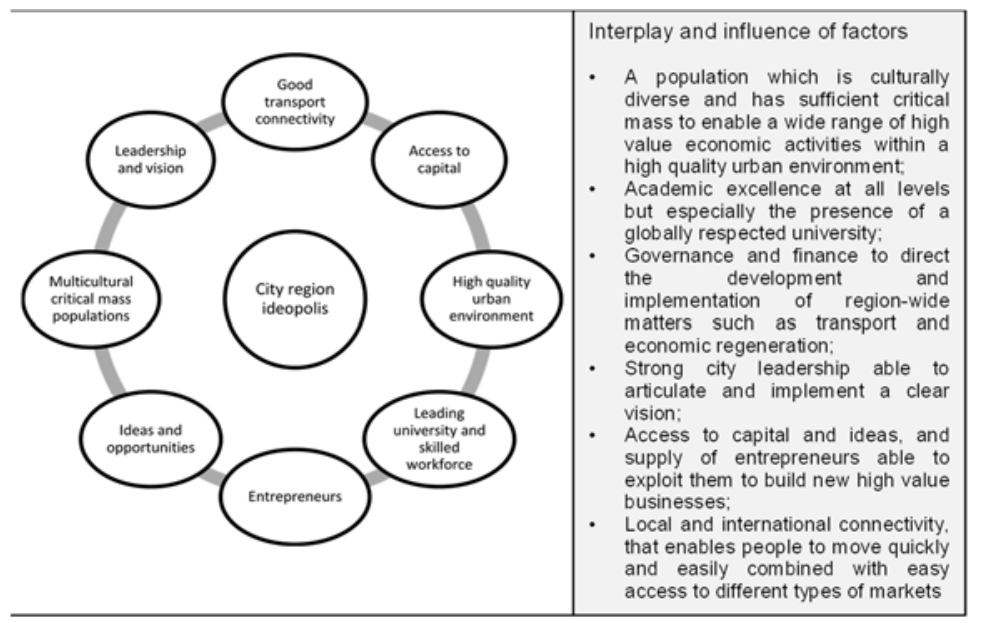

Figure 1: Interplay of ideopolis factors. (Source: World Foundation, Barry [11].)

economic and political) [7]. In the successive discussions, this paper presents an approach that incorporates the idea that sustainability is a way of securing quality of life [1] and/or quality of life is the integral part of sustainability.

\section{TRENDS IN SUSTAINABILITY AND QUALITY OF LIFE}

Sustainable development aims to achieve a continuous improvement in citizens' quality of life and well-being [7]. A significant number of UN publications and reports state that cities have a mammoth role to play in achieving sustainable urban development and modes of living. A point of departure would be defining a sustainable urban neighbourhood; however, this is a difficult task in itself as it is prone to different conceptualisations and interpretations. Notwithstanding these postulated inconsistencies, there is an extensive consensus in the literature that sustainability is a blanket term covering environmental, social and economic dimensions - termed the three pillars of sustainability. These dimensions concern quality of life as they comprise various elements related to the environment, the economy and society [8]. UN-Habitat and UNEP [12] have intertwined these themes of sustainable development and define a sustainable city as a city where achievements in social, economic and physical development are made to last.

Parallel (or resulting) sustainability has emerged to seek to understand the fundamental character of the interactions between nature and society [13] and the principal instruments for conveying sustainable neighbourhood development. Approaching this from a quality of life perspective, the quality of the environment and/or status of the environment is relatively favourable or continuously improving if it is a foundation for leading healthy and good lives [1], thus embracing quality of life and an unequivocal provision of sustainability. On the basis of this overlapping between quality of urban life and urban sustainability, much effort is put into the sustainability paradigm as a way of providing quality of life [8]. Secondly, though urban sustainability and quality of urban life are both premised on social, economic and environment principles, sustainability, therefore, is about more than just quality of life its mandate extends to understanding the connections between these principles and achieving balance [8], alignment and integration among them. As such, and illustrative of these five dimensions of urban sustainability, the need for comprehensive information is key in 
planning for sustainable development [14] to improve quality of life. This point is substantiated by the statement that economic, social and environmental implementation efforts need to be reintegrated and future sustainable development goals need to be thought of as dimensions of the sustainable development paradigm [12].

The central contention is that for a neighbourhood/city to achieve fully fledged sustainability, it has to embrace sustainability multi-dimensionalism as a basic aim to coordinate diverse agendas related to land use, energy, water, waste, mobility, health and education, economic development, and the promotion of cultural vitality and social inclusion [14]. Thus, the UN [15] stipulates that the road to sustainable development cannot be paved with half measures. The wave of interest in this regard is sustainability coverage and its ability to necessitate a cross-cutting approach to actualise sustainability in urban life. For example, due to a rapid increase of urbanisation, neighbourhoods, the built environment, public transportation and services should be considered simultaneously [16]. In essence, no neighbourhood/city can be sustainable without encompassing the sustainability dimensions and key components of urban sustainability. Having brought to light the imperativeness of integrating sustainable development dimensions, which systematic and integrative mechanisms would optimise the interactions between urban sustainability dimensions and urban planning systems, and effectively deliver expected sustainability outcomes, is a key question here. In various reviews and reflections offered, integrated assessment modelling instruments (modelling tools and appraisal frameworks) are considered central to the processes of integrated sustainability, urban systems and sustainability agendas such as achieving the desired quality of life.

\subsection{Integration: strategic approach to sustainability}

To approach integrated sustainability, consequent improvements are prerequisite in all identified levels of urban planning systems and the areas discussed. Notably, urban sustainability multi-dimensions are often being treated separately, and as a result will not suffice to achieve desired urban sustainability [17]. The integration of sustainability principles creates an opportunity to frame urban sustainability for assessment purposes aimed at measuring sustainable urban development progress. Although integrated sustainability is a descriptive analytical framework, its unifying organisational structure can perform the descriptive analytical task of sustainability assessment [17]. It is, in essence, a methodological framework for formulating a city or neighbourhood's sustainability index. Taking the traditional three pillars of sustainable development to illustrate this point, the economic, environmental and social impacts in neighbourhoods are captured simultaneously; therefore, the results are also reported simultaneously. Adopting a more complex scenario, if spatial patterns can be approached in this manner this would provide a solid basis to deduce sources of spatial urban growth and give an account of its interaction with its sources such as economic, population and environmental factors [18] - thus, simultaneous sustainability assessment.

As a result, indicators that can respond to city/neighbourhood problems such as distorted neighbourhood growth direction, spatial inequalities and necessities, food security, demographic diversity, environmental degradation, socio-economic challenges, and connectivity and mobility challenges can be selected. Therefore, by integrating the sustainability strategy, identified and/or selected indicators can be used to organise or construct themes for sustainability assessment. In line with the aim of this paper, this strategy outlines the practicability of the neighbourhood sustainability assessment framework. 


\section{URBAN SUSTAINABILITY ASSESSMENT TOOLS}

Ideas, thinking and valiant attempts to measure/evaluate sustainability and sustainable development have predominated in the last decades in most disciplines and sectors [19]. The literature review provides a sequential account of the following sustainability assessment models in the urban context: Strategic Environmental Assessment (SEA); Dashboard of Sustainable Development; Building Research Establishment's Environmental Assessment Method (BREEAM); Sustainability Building Tool (SBTool); Leadership in Energy and Environmental Design (LEED); BREEAM Communities; LEED-Neighbourhood Development, Sustainable Communities Tools (SCTool); Comprehensive Assessment System for Built Environment Efficiency-Urban Development (CASBEE-UD); EarthCraft Communities (or Green Star Communities); and The CASBEE-City.

These methods provide the general structure for the sustainability-related performance measurement and/or operationalising sustainability by providing performance benchmarks. Interesting to our evaluation is that these methods' purveyance comparisons of municipalities, urban areas and neighbourhoods serve as a platform to aid decision-making processes, thus benefiting authorities, planners and other urban practitioners [16]. Germane to the subject of this paper is a point that these methods seek a way to address some constraints that need to be overcome to achieve sustainability in neighbourhoods. They embrace a comprehensive approach; for example, they require and consider the possibilities of evaluating components of building simultaneous to public transport, services, the environment, the built environment and people [16].

On the other hand, there are constraints that these sustainability assessment tools need to overcome, including but not limited to: providing an insufficient account of sustainability (not all-inclusive); inadequacy of instruments for addressing the local-specific issues; and adaption and inadequacy of instruments to be linked to other performance indicators. Looking at all of the assessment tools discussed here, the environmental field is by far the most developed and consistently integrated in various tools. In reaction to the nature of such deficiencies, Purvis and Grainger [20] point out that it is surprising how little progress has been made in producing models of sustainable urban development attuned to the evident interest in modelling as a tool to support sustainable development and the importance of cities as development centres. This statement is coincident with the comprehensive assessment framework this research paper desires to achieve.

\section{SUCCESSFUL NEIGHBOURHOOD MODEL}

The Successful Neighbourhood Model (SNM) is introduced as a comprehensive urban sustainability assessment framework/tool. The groundwork for the development of SNM is a literature review of the key principles of sustainable development, sustainable development/sustainability science, the principles of sustainability in the urban (planning) context, urban sustainability assessments methods and urban systems. Urban systems have become the locus of urban sustainability. According to Bretagnolle et al. [21], urban system models have to be theoretically parsimonious and factually consistent with the applicable urban system (in this case, with the neighbourhood scale), surveys and statistical observation, in order to come as close as possible to what could be a validation by a simulation model. This can pose a challenge - urban systems are very difficult to delimitate as they are open and overlapping [20]. On the other hand, the overlapping of urban systems initiate possible leverage points to enhance and/or forge integration of neighbourhood sustainability indicators. This element can be used to delimit and/or refine model tools (indicators and factors) in the science-specific context in order to measure and evaluate neighbourhood sustainability objectively. 


\subsection{Model design}

It is important to mention here that models are of central importance in many scientific contexts [22]. In general, literature acknowledges that there is a protocol-scientific processes and systems to be followed. In this case, the SNM integrative dimension and analytical tool provides a generic framework and sustainability assessment protocol. The model is formulated within the South African context and/or fits its conditions.

\subsubsection{Neighbourhood scale and sustainability assessment efficacy}

Places ranging in scale from the individual dwelling or local neighbourhood, to the city and region, and even the state or nation, influence people's lives and, thus, their overall quality of life [8], thus making the neighbourhood a central component of SNM. Despite the contested nature of sustainability as a concept, it is understood that a neighbourhood is a level with significant implications for sustainable development. Sustainability principles suggest that a neighbourhood is a level at which socio-economic impacts can be better analysed and citizen involvement can be easier and more meaningfully facilitated. Based on these dimensions, the neighbourhood unit is expected to provide a sufficient account of the sustainability indicators - relevant indicators in pursuit of sustainability practices that would allow measuring the level of neighbourhood sustainability performance. Despite the contested nature of sustainability as a concept, it is understood that a neighbourhood is a level with significant implications for sustainable development.

\subsubsection{Framing and grouping indicators}

A systems approach to the formulation of the neighbourhood sustainability evaluation model is the development of indicators related to neighbourhood unit principles based on the idea of sustainable urban form and urban system concepts. In the urban planning context, generally, the urban systems are approached through land use, which is evaluated respectively from its environmental, economic and social sustainability [23]. As previously mentioned, space is a place of transfer to undertake sustainable urban planning and improve the quality of life. As a result, it must be represented in sustainability interpretations and frameworks. This makes spatial measures prerequisite to achieving sustainable urban form.

At this juncture, the focus of the work is on the frame formulation - indicators that are defined on the bases of their dimensionality and measurable parameters to evaluate neighbourhood sustainability. The indicators are tools that can be used to collect and organise information in a manner that is useful in conceptualising, evaluating, implementing and communicating sustainable neighbourhood and quality of life. The sustainability principles are refined and translated into neighbourhood to coin a frame - this general structure is called SNM.

The term successful neighbourhood is conceptualised from an extensive literature review, putting in to perspective all the pillars of sustainable development and principles of urban sustainability that promote sustainable modes of living and spatial, transportation and environmental management transformation. The word successful is an acronym of the following ten themes of neighbourhood sustainability indicator groups: spatial/environment; urban density; culture and social; connectivity and mobility; economic; smart growth; service quality; food security; urban governance; and liveability (shown in Table 1). 
Table 1: The SNM - refined SNM sustainability indicators.

\begin{tabular}{|c|c|}
\hline Indicator group & Measurement of factor(s) \\
\hline \multicolumn{2}{|l|}{ Spatial/environment } \\
\hline \multirow[t]{2}{*}{$\begin{array}{l}\text { Locational advantages/ } \\
\text { opportunities }\end{array}$} & $\begin{array}{l}\text { Average neighbourhood proximity to CBD at various categories: Excellent } \\
(\leq 2.5 \mathrm{~km}) \text {; Good }(2.501-5 \mathrm{~km}) \text {; Moderate }(5.001-7.5 \mathrm{~km}) \text {; Poor }(7.501-10 \mathrm{~km}) \text {; } \\
\text { Insignificant }(10.001 \mathrm{~km}+)\end{array}$ \\
\hline & $\begin{array}{l}\text { Average neighbourhood proximity to work at various categories: Excellent } \\
(\leq 2.5 \mathrm{~km}) \text {; Good }(2.501-5 \mathrm{~km}) \text {; Moderate }(5.001-7.5 \mathrm{~km}) \text {; Poor }(7.501-10 \mathrm{~km}) \text {; } \\
\text { Insignificant }(10.001 \mathrm{~km}+)\end{array}$ \\
\hline Residential land use & $\begin{array}{l}\text { Residential land use (total \# of formal houses or brick structures on separate } \\
\text { stands)/ business land use (total \# of business structures) = \% of mixed land use } \\
\text { per neighbourhood }\end{array}$ \\
\hline \multicolumn{2}{|l|}{$\begin{array}{l}\text { Urban density: Unequal } \\
\text { distribution of urban } \\
\text { population }\end{array}$} \\
\hline Concentration ratio (CR) & $\begin{array}{l}\text { The proportion of inequality in the distribution of population in relation to the } \\
\text { area = the redistributed } \% \text { of the city's population to produce an exact } \\
\text { correspondence between population size and land area. Normalised } \\
\text { neighbourhood concentration ratio = Excellent }(0-0.2) \text {; Good }(0.21-4.0) \text {; } \\
\text { Moderate }(0.41-0.6) \text {; Poor }(0.61-0.8) \text {; Insignificant }(0.81-1.0)\}\end{array}$ \\
\hline \multicolumn{2}{|l|}{ Cultural and social } \\
\hline \multirow[t]{3}{*}{$\begin{array}{l}\text { Inclusive planning and } \\
\text { implementation }\end{array}$} & $\begin{array}{l}5 \text {-year neighbourhood involvement growth rate }=[\text { total \# of people involved in } \\
\text { the neighbourhood regeneration project } \mathrm{t}-\text { total \# of people involved in the } \\
\text { neighbourhood regeneration project_(t-5)]/[total \# of people involved in } \\
\text { the neighbourhood regeneration project_(t-5)] }=\%\end{array}$ \\
\hline & $\begin{array}{l}\text { [Total \# of neighbourhood voting population] / [total neighbourhood population] } \\
=\% \text { voting population per neighbourhood }\end{array}$ \\
\hline & $\begin{array}{l}\text { [Total \# of citizens participating in community life and decision-making] / [total } \\
\text { neighbourhood population] }=\% \text { of community involvement }\end{array}$ \\
\hline Social capital & $\begin{array}{l}\{\text { Total \# of social (organisations/activities) in neighbourhood }\} /\{\text { total \# of } \\
\text { (organisations/activities) in the city }\}=\%\end{array}$ \\
\hline Visitors & $\begin{array}{l}\{\text { Total \# of neighbourhood (hotels and guest) rooms recorded }\} /\{\text { total \# of the } \\
\text { city (hotels and guest) rooms }\}=\%\end{array}$ \\
\hline \multicolumn{2}{|l|}{$\begin{array}{l}\text { Connectivity and public } \\
\text { transport }\end{array}$} \\
\hline Public transport usage & $\begin{array}{l}\text { (\# public transport usage in residential neighbourhood) } / \text { (\# of public transport } \\
\text { usage in all the residential neighbourhoods) }=\%\end{array}$ \\
\hline \multirow[t]{2}{*}{ Accessibility } & $\begin{array}{l}\text { The neighbourhood average access time of public transport in terms of waiting } \\
\text { time / the average (for all the neighbourhoods) access time of public transport in } \\
\text { terms of waiting time }=\% \text { of neighbourhood public transport access time per city }\end{array}$ \\
\hline & $\begin{array}{l}\text { Average daily \# of taxi available seats within } 30 \text { minutes or } 2 \mathrm{~km} \text { radius of the } \\
\text { neighbourhood } / \text { total neighbourhood population }\}=\%\end{array}$ \\
\hline $\begin{array}{l}\text { Affordability and } \\
\text { payment }\end{array}$ & $\begin{array}{l}\{\text { Total \# of households spending }>10 \% \text { of income on transport fare }\} / \text { total } \# \text { of } \\
\text { neighbourhood households }\}=\% \text { of households spending more than } 10 \% \text { of } \\
\text { income on transport fare }\end{array}$ \\
\hline \multirow[t]{2}{*}{ Road infrastructure } & $\begin{array}{l}\text { Road network }(\%)=\{\text { demand in terms of } \mathrm{km} \text { of road to be tar in the } \\
\text { neighbourhood }\} / \text { total neighbourhood road network in } \mathrm{km}\}\end{array}$ \\
\hline & $\begin{array}{l}\text { Road maintenance demand }(\%)=\{\text { neighbourhood road high demand for } \\
\text { maintenance in } \mathrm{km}\} / \text { total neighbourhood road network in } \mathrm{km}\}\end{array}$ \\
\hline Traffic convenience & $\begin{array}{l}\text { (Average neighbourhood travel time per day) / (average travel time per day in all } \\
\text { the residential neighbourhoods) } \times 100=\%\end{array}$ \\
\hline
\end{tabular}


Table 1: Continued.

\begin{tabular}{|c|c|}
\hline Indicator group & Measurement of factor(s) \\
\hline \multicolumn{2}{|l|}{ Economic } \\
\hline \multirow[t]{2}{*}{ Economic characteristics } & $\begin{array}{l}\%=(\text { the } \# \text { of people in the neighbourhood whose income is less than } \$ 1.25 \text { a } \\
\text { day) / (neighbourhood population) }\end{array}$ \\
\hline & $\begin{array}{l}\text { Measure the neighbourhood's household incomes by calculating the \% of the } \\
\text { whole neighbourhood population that can be categorised by social housing: no } \\
\text { wage income (R0) fully subsidised; very low income }(<\mathrm{R} 1500) \text { fully subsidised } \\
\text { ownership; low income (R1500-R3500) rental and partly subsidised } \\
\text { ownership; middle income (R3500-R7500) rental; high income } \\
\text { (R7500-R8001) no rental and ownership, gap housing }\end{array}$ \\
\hline \multirow[t]{2}{*}{ Human capital } & $\begin{array}{l}\{\text { Residential neighbourhood employed } \#\} /\{\text { neighbourhood labour force } \\
\text { (i.e. employed + unemployed })\}=\%\end{array}$ \\
\hline & $($ Residential neighbourhood unemployed \#) $/($ neighbourhood population $)=\%$ \\
\hline $\begin{array}{l}\text { Economic vitality and } \\
\text { market }\end{array}$ & $\begin{array}{l}\text { \{\# of the people that own the dwelling in which they live }\} /\{\text { total } \\
\text { neighbourhood population }\}=\%\end{array}$ \\
\hline \multicolumn{2}{|l|}{ Smart growth } \\
\hline Multiple transport options & Total \# of neighbourhood transport options / city transport options $=\%$ \\
\hline $\begin{array}{l}\text { Range of housing } \\
\text { opportunities }\end{array}$ & $\begin{array}{l}\text { Total \# of neighbourhood residential dwelling houses options / total \# of city } \\
\text { residential dwelling houses options }=\% \text { of neighbourhood residential dwelling } \\
\text { houses options }\end{array}$ \\
\hline \multirow[t]{2}{*}{ Sense of place } & $\begin{array}{l}\text { Total \# of people in the neighbourhood that are involved in public participation } \\
\text { activities / total neighbourhood population }=\%\end{array}$ \\
\hline & $\begin{array}{l}\text { (\# of people living in the neighbourhood for more than } 10 \text { years) } / \\
\text { (neighbourhood population) }=\%\end{array}$ \\
\hline \multicolumn{2}{|l|}{$\begin{array}{l}\text { Services (parks/sport } \\
\text { fields/education/transport/ } \\
\text { housing services) }\end{array}$} \\
\hline \multirow[t]{5}{*}{ Housing services coverage } & $\begin{array}{l}\text { (Total \# of households with piped water connection in the neighbourhood) } / \\
\text { (total \# of households in the neighbourhood) }=\%\end{array}$ \\
\hline & $\begin{array}{l}\text { (Total \# of households with electricity connection in the neighbourhood) / (total } \\
\text { \# of households in the neighbourhood) }=\%\end{array}$ \\
\hline & $\begin{array}{l}\text { (Total \# of households with access to refuse removal) / (total \# of households in } \\
\text { the neighbourhood })=\%\end{array}$ \\
\hline & $\begin{array}{l}\text { (Total \# of households with flush toilets in neighbourhood) / (total \# of } \\
\text { households in the neighbourhood) }=\%\end{array}$ \\
\hline & $\begin{array}{l}\text { Urban housing }=\text { (current demand for RDP housing in neighbourhood) } / \\
\text { (current demand for RDP housing in the urban area) }=\%\end{array}$ \\
\hline \multirow[t]{4}{*}{ Accessibility index } & Average travel distance $(\mathrm{km})$ for (facility/service) \\
\hline & $\%$ of neighbourhood beneficiaries (target population) within $3 \mathrm{~km}$ of facilities \\
\hline & $\%$ of neighbourhood beneficiaries (target population) within $5 \mathrm{~km}$ of facilities \\
\hline & Worst case travel distance $(\mathrm{km})$ for (facility/service) \\
\hline \multicolumn{2}{|l|}{ Food security } \\
\hline \multirow[t]{2}{*}{ Availability } & $\begin{array}{l}\text { (Total \# of households in the neighbourhood that are involved in food } \\
\text { production) / (total \# of households in the neighbourhood) }=\%\end{array}$ \\
\hline & $\begin{array}{l}\text { (Total \# of community functional food production projects in neighbourhood) / } \\
\text { (total \# of community functional food production projects in all the residential } \\
\text { neighbourhoods) }=\%\end{array}$ \\
\hline
\end{tabular}


Table 1: Continued.

\begin{tabular}{|c|c|}
\hline Indicator group & Measurement of factor(s) \\
\hline \multicolumn{2}{|l|}{ Urban governance } \\
\hline Human capital & $\begin{array}{l}\text { Measure the local municipality human capital by considering: shortage; } \\
\text { specialised skills; implementation capacity; provisioning for all specialised } \\
\text { skills; and outsourcing to consultants }\end{array}$ \\
\hline Database & $\begin{array}{l}\text { Measure local municipality database by considering: updating consistency; } \\
\text { reliability; integration between the different spheres of government; GIS data; } \\
\text { completeness in terms of land use data, service data and transport data }\end{array}$ \\
\hline $\begin{array}{l}\text { Integration between/within } \\
\text { the three spheres of } \\
\text { government }\end{array}$ & $\begin{array}{l}\text { Measure the integration between/within the three spheres of government in } \\
\text { terms of: linkages between the planning in the three spheres of government and } \\
\text { the IDP; linkages between the programs in the three spheres of government and } \\
\text { the IDP; linkages between the budgets in the three spheres of government and } \\
\text { the IDP; integrated monitoring of expenditure on all three spheres of } \\
\text { government; integrated monitoring on all three spheres of government if } \\
\text { programs/projects are finished (on time and within projected budget) }\end{array}$ \\
\hline Elimination of backlogs & $\begin{array}{l}\text { Measure the local municipality backlogs in: piped water connections; electricity } \\
\text { connections; refuse removal; flush toilets; RDP housing }\end{array}$ \\
\hline Operational factors & $\begin{array}{l}\text { Measure the local municipality operational factors in terms of: operators } \\
\text { adequate training or professional competency; information systems' } \\
\text { effectiveness in monitoring operations; timelines and professional competency; } \\
\text { operation's budget to actual financial variance for major budget categories; } \\
\text { level of communication or understanding by decision makers }\end{array}$ \\
\hline $\begin{array}{l}\text { Maintaining existing } \\
\text { infrastructure }\end{array}$ & $\begin{array}{l}\text { (\# of days per annum that any residential neighbourhood in the urban area was } \\
\text { without water }=0)+(\# \text { of days per annum that any residential neighbourhood } \\
\text { in the urban area was without water }=1)+(\# \text { of days per annum that any } \\
\text { residential neighbourhood in the urban area was without water }=2)+(\# \text { of days } \\
\text { per annum that any residential neighbourhood in the urban area was without } \\
\text { water }=3)+(\# \text { of days per annum that any residential neighbourhood in the } \\
\text { area was without water }>3)\end{array}$ \\
\hline $\begin{array}{l}\text { Infrastructure programs and } \\
\text { projects }\end{array}$ & $\begin{array}{l}\text { Measure the local municipality infrastructure programs and projects by } \\
\text { considering: prioritised projects before budget distribution; timeously planning } \\
\text { and design of new infrastructure; changes in the urban form (growth and spatial } \\
\text { changes); current and future traffic congestion levels; areas where there is a } \\
\text { need for congestion management }\end{array}$ \\
\hline \multicolumn{2}{|l|}{ Liveability } \\
\hline Cost of living & $\begin{array}{l}\{\text { Average rent price levels in the residential neighbourhood for a }(2 \text { bedroom } / 3 \\
\text { bedroom } / 4 \text { bedroom) house }\} / \text { average rent price levels in all the residential } \\
\text { neighbourhoods for a }(2 \text { bedroom } / 3 \text { bedroom } / 4 \text { bedroom }) \text { house }\}=\%\end{array}$ \\
\hline Security and safety & $\begin{array}{l}\{\text { Total \# of recorded (murders and housebreakings) in neighbourhood }\} / \text { total \# } \\
\text { of (murders and housebreakings) in all the residential neighbourhoods }=\%\end{array}$ \\
\hline $\begin{array}{l}\text { Living environment and } \\
\text { healthcare }\end{array}$ & $\begin{array}{l}\text { (Total \# of medical doctors in } 5 \mathrm{~km} \text { radius from the neighbourhood centre) } / \\
\text { (total population of the neighbourhood) }=\% \text { of neighbourhood medical doctors } \\
\text { per population }\end{array}$ \\
\hline \multirow[t]{2}{*}{ Stability } & $\begin{array}{l}\text { (Total capacity of all public healthcare services in } 10 \mathrm{~km} \text { radius from the } \\
\text { neighbourhood centre) / (total population in the services access distance) }=\%\end{array}$ \\
\hline & $\begin{array}{l}\text { (Crime incidents in the neighbourhood) } / \text { (total population of the } \\
\text { neighbourhood) }=\%\end{array}$ \\
\hline
\end{tabular}

CBD: Central Business District; RDP: Reconstruction and Development Programme; IDP: Integrated Development Plan. 
These indicators are supported by a set of factors that fit the specifics and conditions of the neighbourhood being assessed. In addition, these factors are measurable and quantifiable for measurement purposes.

\subsubsection{Integrating indicators and redefining factors}

Based on the selected key features of sustainable neighbourhood development, the research has identified the most potentially relevant neighbourhood sustainability indicators that can contribute to the development of sustainable urban neighbourhood form, measured in terms of the indicators' ten themes and a vast array of relevant factors by applying an appropriate Multi-Criteria Analysis (MCA). At this stage, factors that are similar and overlapping are eliminated/combined and/or modified to fit the specifics of the different theme/indicator group and situation being measured. At the end the weighting and scoring system facilitates a comparison, ordering and ranking of neighbourhoods by their measure of sustainability level. As a result, the value of the sustainability index will make the combination of management decisions and theoretical results possible, and will provide a scientific guideline and decision-making process for the better implementation [23] of dynamic neighbourhood initiatives and strategies.

\section{SNM APPLICATION: COMPARATIVE REVIEW AND RANKING OF NEIGHBOURHOOD SUSTAINABILITY}

The SNM procedure comprises a metric benchmarking methodology. The applied method of SNM operationalisation is MCA - its suitability for sustainability evaluation and the adequacy of decision-making requirements are entrenched in its systematic approach, which includes the careful consideration of indicator selection, weighting and ranking. This is used as a means of sustainability assessment and/or performance evaluation as it makes it easy and more efficient for SNM to measure the level of sustainability initiatives and to enable a comparative analysis and ranking of alternatives and neighbourhoods. With weighting assigned, the comparison matrix can be used to determine the relative importance of each indicator and then between the categories/groups/neighbourhoods. The data integrated into the framework will provide perspective in assessing sustainability, prioritising and ranking neighbourhoods. This means that quantitative data as determined by the indicators - each neighbourhood's weights are calculated. This is done by calculating the weights for each criterion separately and adding them together for each of the neighbourhoods, as demonstrated in Table 2.

In turn, this highlights SNM interactive and integrative propensity - linking physical, social, economic, ecological and institutional dimensions to provide a basis for rating and deriving a neighbourhood-specific approach. Another fundamental character of this interaction is the promotion of the integration and connectivity between urban components for them to function as integrated and interconnected communities. To create the basis for better integration and sustainability, the comparative review results can, in turn, be optimised to cross-evaluate indicators' applicability in different parts of each neighbourhood. These procedures outline the complete spectrum of SNM decision strategies to provide an overall alternative ranking. The SNM output will then be interpreted and comprehensive accounts of cases' phenomena positioned within the context of the entire city.

\section{EXPECTED OUTCOMES FOR THE QUALITY OF LIFE}

Through SNM a wider range of quality of life factors will come into play, such as social activity and perception of individual inhabitants, which urban planners are often criticised for undermining. Arguably, urban planners and designers habitually prioritise the physical 


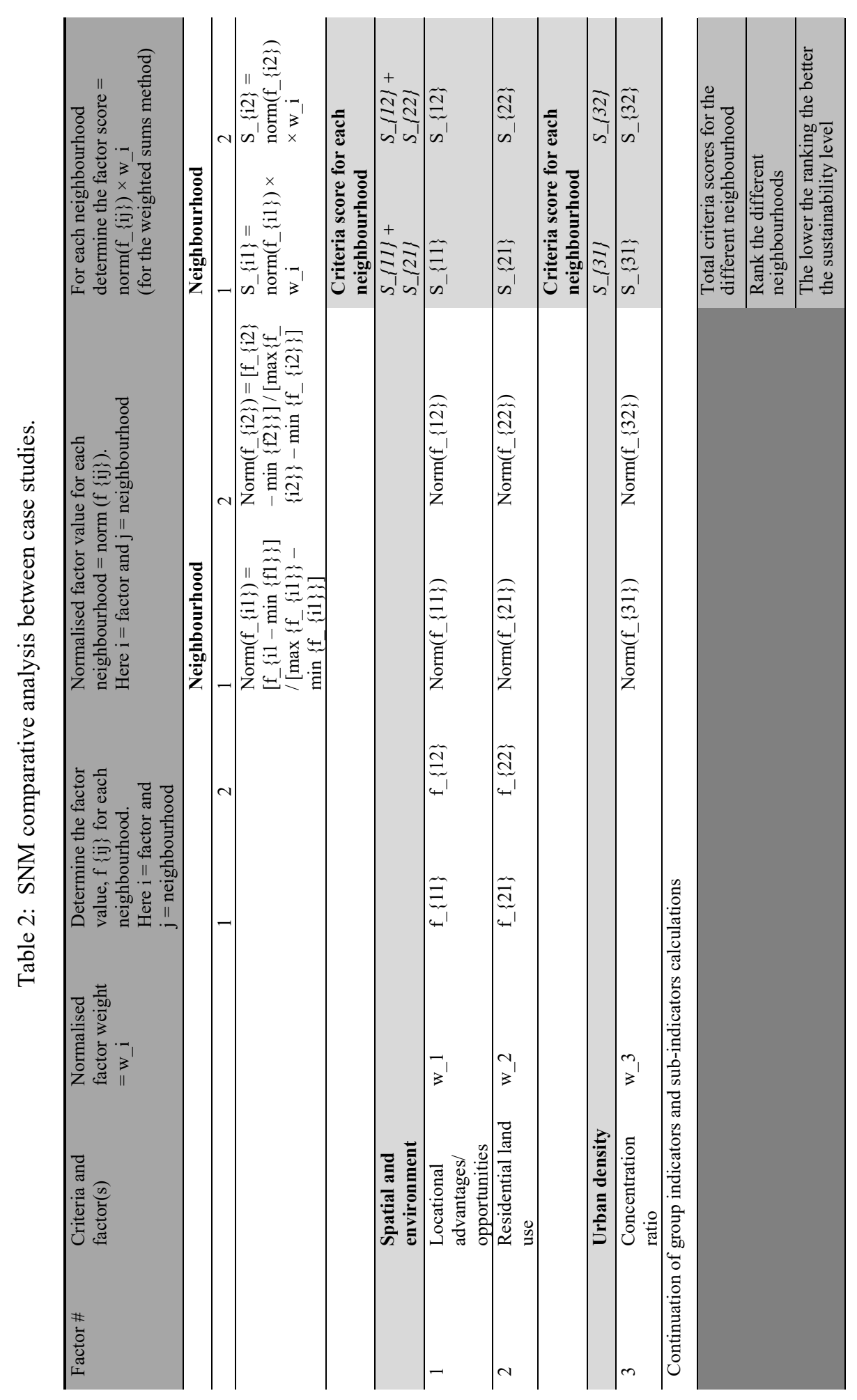


attributes of space [8]. When measuring quality of life, it is important to focus on the measurement of the subjective elements (the individual situation and the person's actual feelings) and the measurement of objective elements (health, education, individual activities such as leisure, status of governance, social connections, status of the environment, personal safety and peace of mind, access to and availability of services) [19]. All of these factors, and more, are sufficiently factored in to SNM. In essence, all attributes of urban sustainability are important to people's quality of life.

\section{RECOMMENDATIONS}

Utilise metrics to increase effectiveness of urban policy intervention: considering the performance evaluation methods discussed, urban policy intervention needs to commit to sustainability measurement frameworks and/or metrics that will hold them accountable to more integrated processes for planning and decision-making.

Combining disciplinary knowledge in order to establish a comprehensive neighbourhood assessment tool: neighbourhood sustainability assessment demands a more expanded approach. It is recommended that combined disciplinary knowledge has to be cultivated to broaden perspectives, allowing disciplines to complement each other in order to establish a comprehensive neighbourhood assessment tool and attain a high level of quality of life.

Additional indicators/factors to be considered in neighbourhood/city sustainability evaluation: air quality is an important factor that needs to be included in the pool of factors to deal with sustainability performance evaluation in neighbourhoods. For sustainability requirements the focus is on the reduction of pollutants such as vehicle emissions and exploring alternative practices. As a means of assessment, the indicator ought to be included so that it might be used to permit comparisons to the situations. However, the air pollution monitoring points are not neighbourhood-specific and, therefore, do not provide any accurate performance benchmarks.

In addition, though numerous indicators encompass land uses in the model, holistic environmental indicators have to be developed. However, the many factors that determine the quality of the environment are difficult to measure as they exhibit temporary fluctuations [24]. The interrelationship between the environment and the population for site-specific characteristics should preferably be studied over the long term [24].

\section{REFERENCES}

[1] Ministry of the Environment Government of Japan. Annual report on the environment, the sound material-cycle society and the biodiversity in Japan. https://www.env. go.jp/en/wpaper/2010/fulltext.pdf. Accessed on: 6 Mar. 2018.

[2] Grimm, N.B., Redman, C.L., Boone, C.G., Childers, T.B.L. \& Harlan, S., Viewing the urban socioecological system through a sustainability lens: lessons and prospects from the Central Arizona-Phoenix. www.springer.com/content/pdf. Accessed on: 12 Feb. 2016.

[3] Childers, D.L., Pickett, S.A., Grove, M.J., Ogdend, L. \& Whitmer, A., Advancing urban sustainability theory and action: challenges and opportunities. Landscape and Urban Planning, 125, pp. 320-328, 2014.

[4] Myers, D., Building knowledge about quality of life for urban planning. Journal of the American Planning Association, 54(3), pp. 347-358, 1988.

[5] Pacione, M., Urban Geography: A Global Perspective, Routledge: New York, 2005.

[6] Yuan, L., Yuen, B. \& Low, C., Urban quality of life, University of Singapore, 1999.

[7] Eurostat. http://europa.eu/eurostat/statisticsexplained/index. Accessed on: 12 Mar. 2018. 
[8] Alvarez, A.L. \& Muller-Eie, D., Quality of urban life and its relationship to spatial conditions. WIT Transactions on Ecology and the Environment, vol. 223, pp. 285-296, 2017.

[9] Economist Intelligence Unit. www.eiu.com/liveability. Accessed on: 12 Mar. 2018.

[10] Jones, A., Williams, L., Lee, N., Coats, D. \& Cowling, M., Ideopolis: Knowledge City Regions, 2000.

[11] Barry M., Metro for Wales' capital city region, a connecting Cardiff, Newport and the Valleys, 2011.

[12] UN-Habitat \& United Nations Environment Programme. Sustainable Cities Program, 2001.

[13] Clifford, N., Holloway, S. \& Rice, S.P., Key Concepts in Geography, SAGE Publications: London, 2008.

[14] UN-Habitat. The Future We Want. The City We Need, 2013.

[15] United Nations. Millennium Development Goals report, 2006.

[16] Haapio, A., Towards sustainable urban communities. Environmental Impact Assessment Review, 32, pp. 165-169, 2012.

[17] Sharifi, A. \& Murayama, A., A critical review of seven selected neighbourhood sustainability assessment tools. Environmental Impact Assessment Review, 38, pp. 73-87, 2013.

[18] Cohen, M., A systematic review of urban sustainability assessment literature. Sustainability, 2017.

[19] Passerini, G. \& Brebbia, C.A., Environmental Impact II, WIT Press: Southampton, 2014.

[20] Purvis, M. \& Grainger, A., Exploring Sustainable Development: Geographical Perspectives, Earthscan: London, 2013.

[21] Bretagnolle, A., Daudé, E. \& Pumain, D., From theory to modelling: urban systems as complex systems. Cybergeo, 335, 2006.

[22] Frigg, R., Scientific representation and the semantic view of theories. Theoria, 55, pp. 49-65, 2006.

[23] Xu, Z. \& Coors, V., Combining system dynamics model, GIS and 3D visualization in sustainability assessment of urban residential development. Building and Environment, 47, pp. 272-287, 2012.

[24] National Research Council (US), Techniques for the Study of Primate Population Ecology, National Academy Press: Washington, DC, 1981. 